\title{
Influence of Thin Film Quality Control Parameters on the Properties of Spray Coated Tin Monosulfide Thin Films for Photovoltaic Application
}

\author{
Siddhant B. Patel and Jignasa V. Gohel ${ }^{*}$ \\ *Chemical Engineering Department, SVNIT, Surat, India.
}

\begin{abstract}
In the present study, a p-type tin monosulfide (SnS) thin films are prepared using a low-cost spray pyrolysis technique. The optical, structural and morphological properties are studied in detailed. The thin film quality control parameters are appraised to reduce the presence of secondary phases different to the SnS preferred orthorhombic phase. The substrate temperature $\left(280-440^{\circ} \mathrm{C}\right)$, spraying rate $(4-6 \mathrm{ml} / \mathrm{min})$ and carrier gas pressure (1-2 bar) are varied to optimize the optical, structural and morphological properties of the thin films. Typically, in the case of spray pyrolysis, substrate temperature prominently affects the thin film properties. The same is observed in the present study. At low temperature (280-320 C), lower band gap achieved than preferred 1.5-1.6 $\mathrm{eV}$ and at higher temperature $\left(>400^{\circ} \mathrm{C}\right)$ higher band gap is achieved. The desired band gap is achieved at intermediate temperature $\left(360-400^{\circ} \mathrm{C}\right)$. The XRD analysis is carried out to confirm the optical analysis. The polycrystalline SnS films with orthorhombic structure and a preferential orientation along the (111) plane is observed in X-ray diffraction pattern. However, a secondary phase of $\mathrm{Sn}_{2} \mathrm{~S}_{3}$ is observed at high substrate temperature $\left(>400^{\circ} \mathrm{C}\right)$. The SEM images also suggested that the interval temperature are more preferential for thin film preparation. In addition, the film is applied in solar cell. For film characterization $X$-ray diffraction, scanning electron microscope are used for structural and morphological analysis, respectively. The optical properties are studied using. The solar cell performance is measured using Keithley 2400 solar simulator.
\end{abstract}

Keywords: SnS, thin films, spray pyrolysis, characterization.

\section{Introduction}

There is a great need to increase renewable energy supplies and use more energy efficient technologies and practices, especially as global energy forecasts worsen. The same can be done by converting solar energy to usable energy [1]. However, the cost of pure silicon as well as silicon solar cell preparation cost is marginally high. Hence, thin Second generation thin film solar cells have been introduced to overcome this cost issue [2]. Copper Indium Selenide/ Sulfide (CIS) and cadmium telluride (CdTe) solar cells had attracted so much attention of researchers, but issue with CIS is arability of Indium and with CdTe is toxicity of cadmium the availability of these solar cell in commercial market is limited [3]. Hence, to prepare solar cell with low-cost and high efficiency the other promising materials are being investigated by scientific community.

The tin monosulfide ( $\mathrm{SnS}$ ) belonging to the IV-VI semiconductor group has gained much attention because of its suitable optoelectronic properties for photovoltaic applications. This compound has a direct bandgap near $1.3 \mathrm{eV}$, which is close to the optimal band gap $(1.5 \mathrm{eV})$ of solar cells and has a high absorption coefficient (a> $10^{4} \mathrm{~cm}^{-1}$ ). All SnS elements are abundant, cost-effective and less toxic compared to the CdTe thin films, respectively. $\mathrm{SnS}$ also has p-type electrical conductivity, and it has a theoretical high efficiency greater than $24 \%$ [4].

Several techniques have been employed for preparing SnS films namely: SILAR (successive ionic layer adsorption and reaction) [5], chemical bath deposition (CBD) [6], electron beam evaporation [7], Spray pyrolysis [8], etc. Among these techniques, spray pyrolysis is a versatile and low-cost one. This technique is very attractive; it has been largely used to produce oxide and sulfide.

In the present work, SnS films have been deposited by ultrasonic spray pyrolysis. The effect of substrate temperature on optical, structural, and morphological properties of SnS films has been investigated. In addition, 
to achieve optimum deposition condition, the carrier gas pressure and spraying rate are also varied. Furthermore, solar cell is prepared with the film prepared using optimum condition and solar cell efficiency is measured.

\section{Experimental}

\subsection{Materials}

Tin (II) chloride $\left(\mathrm{SnCl}_{2} \cdot 2 \mathrm{H}_{2} \mathrm{O}\right)$, thiourea $\left(\mathrm{CS}\left(\mathrm{NH}_{2}\right)_{2}\right.$, cadmium acetate $\left(\mathrm{Cd}\left(\mathrm{CH}_{3} \mathrm{COO}\right)_{2}\right)$, zinc acetate $\left(\mathrm{Zn}\left(\mathrm{CH}_{3} \mathrm{COO}\right)_{2} \cdot 2 \mathrm{H}_{2} \mathrm{O}\right)$, aluminum oxide $\left(\mathrm{Al}_{2} \mathrm{O}_{3}\right)$ methanol and isopropyl alcohol (IPA) were purchased from S.D. Fine chemicals, India. Deionized (DI) water was used for washing and solution preparation. Fluorine doped tin oxide (FTO) glass substrate was purchased from Sigma Aldrich. All the chemicals were used as acquired. No further purification was carried out.

\subsection{Methodology}

\subsubsection{Film Preparation}

The spray pyrolysis technique was implemented to prepare tin monosulfide film. The solution for spraying was prepared by dissolving tin chloride and thiourea in methanol. The molar concentration of tin chloride was fixed at $0.1 \mathrm{M}$, and $[\mathrm{Sn}] / \mathrm{S}$ ratio was kept 1 . A clear solution was achieved after stirring for 60 min at room temperature. Consequently, the prepared solution was spray coated on the FTO glass substrate. The deposition conditions were varied in order to obtain an optimum deposition condition. The substrate temperature was varied from $280^{\circ} \mathrm{C}-440^{\circ} \mathrm{C}$ at $40^{\circ} \mathrm{C}$ rise at 1.5 bar carrier gas pressure and $4 \mathrm{ml} / \mathrm{min}$ spraying rate. A compressed air was used as a carrier gas. The distance between substrate and nozzle was kept $20 \mathrm{~cm}$. Further, to optimize deposition condition, the carrier gas pressure and spraying rate were varied as $1,1.5$ and 2 bar and 4, 5 and $6 \mathrm{ml} / \mathrm{min}$, respectively.

\subsubsection{Device Fabrication}

The FTO glass substrates was etched with $\mathrm{Zn}$ powder and diluted $\mathrm{HCl}$ and washed with soap water first, then sonicated in an ultrasonic bath of acetone for $15 \mathrm{~min}$. Further rinsed with distilled water and lastly, dried in vacuum oven. Subsequently, the $\mathrm{SnS}$ film was deposited using optimum deposition condition upon the FTO substrate. Subsequently, CdS layer was deposited on the SnS layer using spray pyrolysis technique. $0.1 \mathrm{M}$ solution was prepared using cadmium acetate and thiourea. Furthermore, upon the CdS layer ZnO layer was deposited by following the method reported in our previous work [9]. A clear solution prepared by dissolving zinc acetate into a mixture of IPA and water $(2: 1)$ and then spray coated at $365^{\circ} \mathrm{C}$ temperature. Finally, counter electrode is prepared using $\mathrm{Al}: \mathrm{ZnO} / \mathrm{FTO}$. $\mathrm{Al}$ doped $\mathrm{ZnO}$ solution is prepared by dissolving aluminum oxide in $\mathrm{ZnO}$ solution and coated upon the FTO substrate.

\subsubsection{Characterization}

The structural properties were determined by XRD using D/Max 2200 system with $\mathrm{CuKa}$ radiation $(\mathrm{CuKa}=$

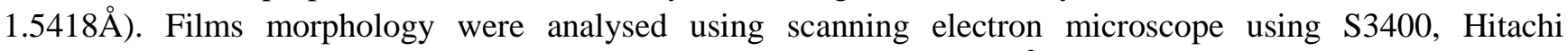
international limited. The band gap was estimated from tauc plot $\left((\alpha h v)^{2}\right.$ vs hv), by extrapolating straight line portion $(\alpha h v)^{2}$ to $\mathrm{x}$-axis (hv) regime (where $\alpha$ is absorbance coefficient and ho is photo energy) using UV-Vis (HACH-DR 6000/2 UV spectrometer) within the range of $300 \mathrm{~nm}$ to $1100 \mathrm{~nm}$ at room temperature. The J-V characteristics of solar cell were recorded using Keithley 2400 under AM 1.5G illumination at $100 \mathrm{~mW} / \mathrm{cm}^{2}$. A xenon lamp was used as source of light.

\section{Results and Discussion}

\subsection{Effect of Substrate Temperature}

The effect of substrate temperature was determined by the optical, structural and morphological analysis. The band gap obtained by film annealed at $280^{\circ} \mathrm{C}, 320^{\circ} \mathrm{C}, 360^{\circ} \mathrm{C}, 400{ }^{\circ} \mathrm{C}$ and $440^{\circ} \mathrm{C}$ are shown in fig. 1 . It was 
observed that at lower temperature $\left(280^{\circ} \mathrm{C}\right.$ and $\left.320^{\circ} \mathrm{C}\right)$ the band gap was higher $(1.8 \mathrm{eV}$ and $1.78 \mathrm{eV})$ than generally reported $1.6-1.75 \mathrm{eV}$ for $\mathrm{SnS}$ film $[10,11]$. In addition, at higher temperature $\left(440^{\circ} \mathrm{C}\right)$ again high band gap $(1.85 \mathrm{eV})$ was observed. At intermediate temperature the band gap was reduced with the range (1.66 and $1.7 \mathrm{eV}$ ). The band gap enlargement can be revealed by XRD analysis (fig. 2). All the films exhibited preferential (111) plane orientation, which suggests generally, reported orthorhombic structure [12-14]. The lower substrate temperature attributed secondary phase of $\mathrm{SnS}_{2}$, whereas at higher temperature a secondary phase of $\mathrm{Sn}_{2} \mathrm{~S}_{3}$ was observed. At intermediate temperature a single phase $\mathrm{SnS}$ film was obtained. In addition, a uniform and dense surface morphology was observed in the SEM images (see fig. 3) at intermediate temperature. However, at low temperature agglomeration of nano particles was observed, whereas at high temperature voids were observed. The lowest band gap is desired for the solar cell application, hence $360^{\circ} \mathrm{C}$ was considered as optimum substrate temperature and used for further experiments.

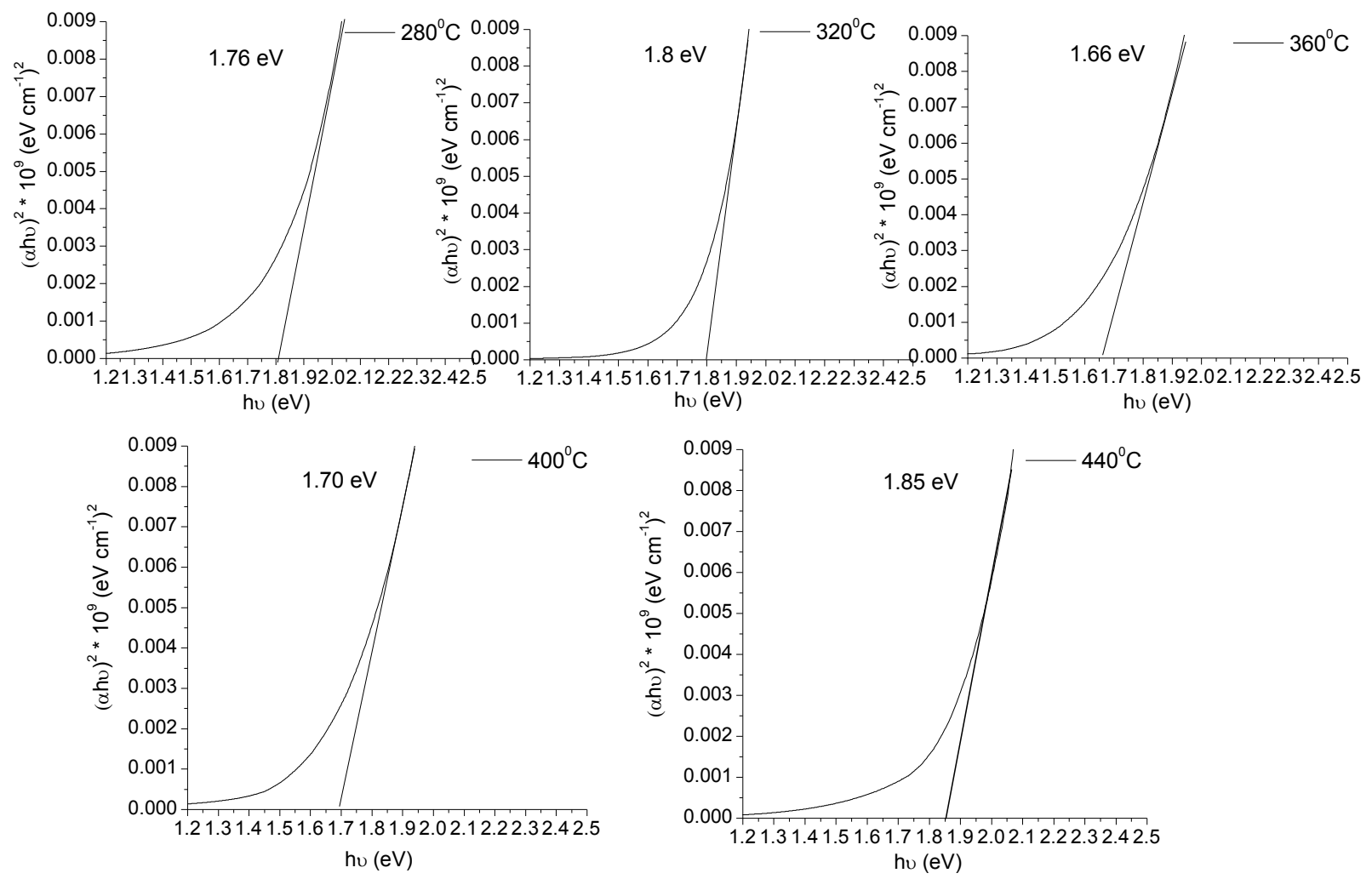

Fig. 1 Tuac's $(\alpha h v)^{2}$ vs ho plot of thin film prepared at different substrate temperature

\subsection{Effect of Carrier Gas Pressure}

The carrier gas pressure exhibited significant effect on the morphological properties of the films, the optical and structural properties were not affected. The surface morphology of the films prepared at different carrier gas pressure are shown in fig. 4 . The substrate temperature and spraying rate were kept constant $360^{\circ} \mathrm{C}$ and $4 \mathrm{ml} / \mathrm{min}$, respectively. The film prepared at 1 bar pressure depicted voids in surface morphology. The increment in pressure led to improvement in morphology. A more uniform and dense film was obtained at 2 bar pressure. Hence 2 bar pressure was considered as optimum pressure and further experiments were carried out at 2 bar pressure. 


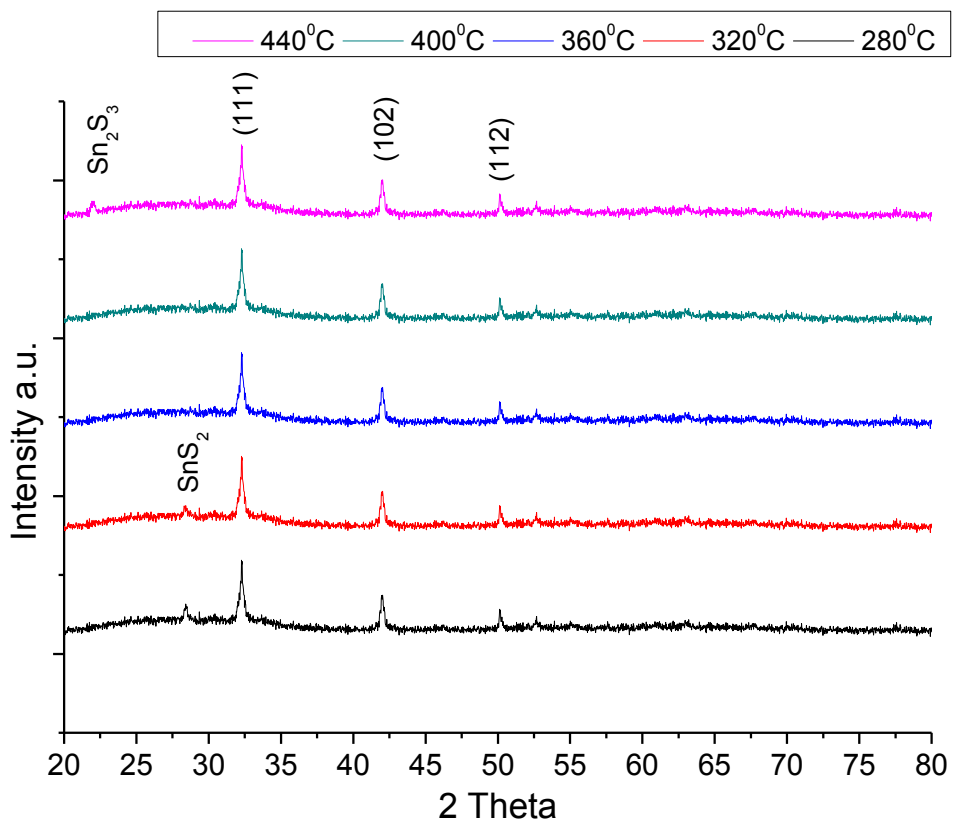

Fig. 2 XRD pattern of thin film prepared at different substrate temperature
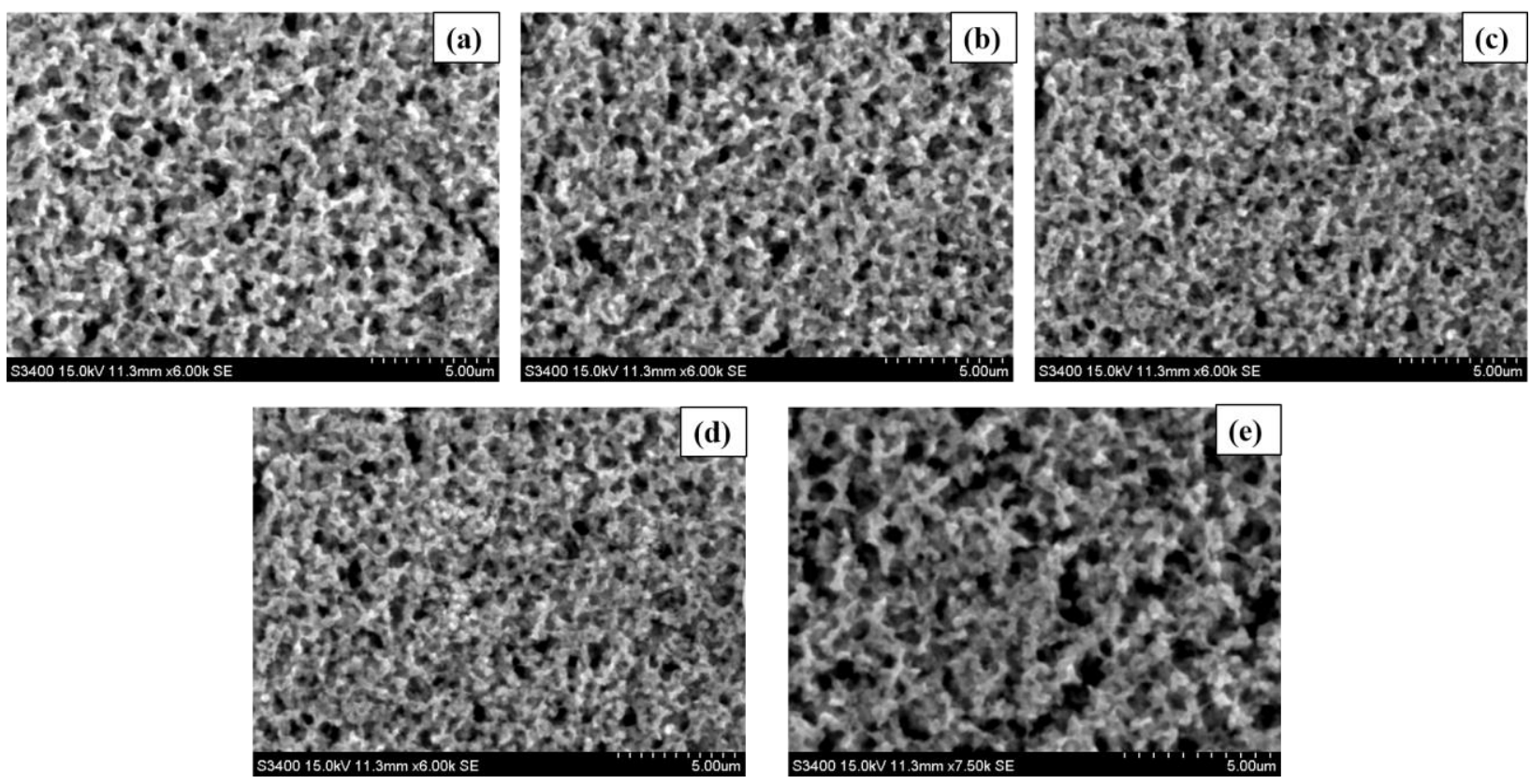

Fig. 3 Surface morphology of thin film prepared at (a) $280^{\circ} \mathrm{C}$, (b) $320^{\circ} \mathrm{C}$, (c) $360{ }^{\circ} \mathrm{C}$, (d) $400{ }^{\circ} \mathrm{C}$, and (e) $440{ }^{\circ} \mathrm{C}$ substrate

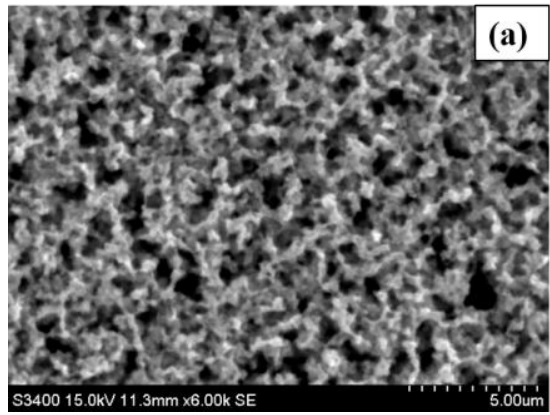
temperature.
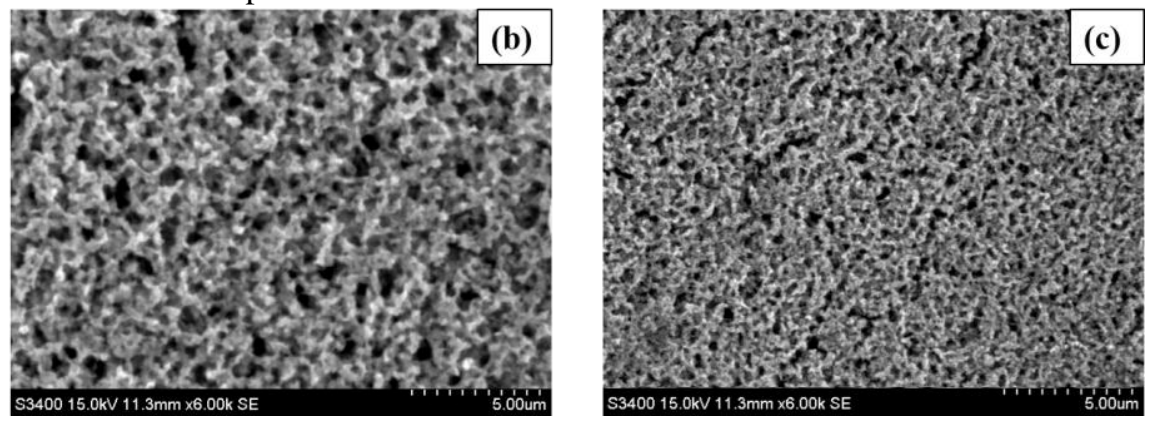

Fig. 4 Surface morphology of thin film prepared at (a) 1 bar, (b) 1.5 bar, and (c) 2 bar carrier gas pressure 


\subsection{Effect of Spraying Rate}

Likewise, carrier gas spraying rate also didn't affected optical and structural properties of the films. The surface morphology of the films prepared at different spraying rate are shown in fig. 5. The substrate temperature and carrier gas pressure were kept constant $360^{\circ} \mathrm{C}$ and 2 bar, respectively. The increment in spraying rate led to improvement in surface morphology, as the films prepared at $5 \mathrm{ml} / \mathrm{min}$ depicted more uniform and dense morphology than film prepared at $4 \mathrm{ml} / \mathrm{min}$. pressure depicted voids in surface morphology. However, further increment in spraying rate led to agglomeration of the particles (Fig. 5c). Hence $5 \mathrm{ml} / \mathrm{min}$ spraying rate is considered as optimum spraying rate.
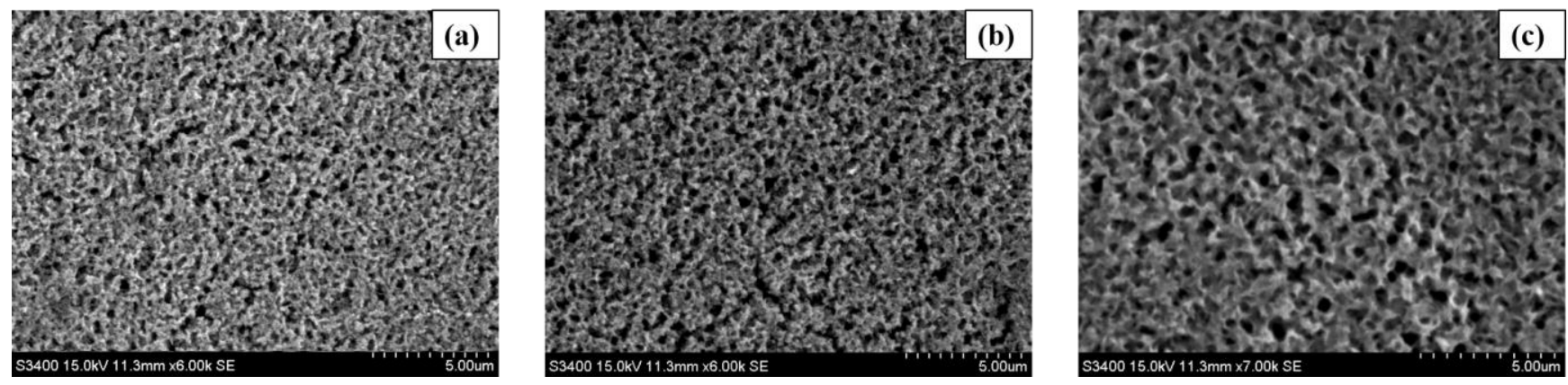

Fig. 5 Surface morphology of thin film prepared at (a) $4 \mathrm{ml} / \mathrm{min}$, (b) $5 \mathrm{ml} / \mathrm{min}$ and (c) $6 \mathrm{ml} / \mathrm{min}$ spraying rate

\subsection{Solar Cell Characteristics}

The solar cell was fabricated using optimum condition (substrate temperature $=360^{\circ} \mathrm{C}$, carrier gas pressure $=$ 2 bar and spraying rate $5 \mathrm{ml} / \mathrm{min}$ ). The solar cell was fabricated as $\mathrm{FTO} / \mathrm{SnS} / \mathrm{CdS} / \mathrm{ZnO} / \mathrm{Al}: \mathrm{ZnO} / \mathrm{FTO}$. Fig. 6 depicts the current density - voltage $(\mathrm{J}-\mathrm{V})$ characteristic of a solar cell for an active area of $0.31 \mathrm{~cm}^{2}$. A current density $\left(\mathrm{J}_{\mathrm{SC}}\right)$ of $7 \mathrm{~mA} / \mathrm{cm}^{2}$, open- circuit voltage $\left(\mathrm{V}_{\mathrm{OC}}\right)$ of $395 \mathrm{mV}$, fill factor $(\mathrm{FF})$ of $38 \%$ and power conversion efficiency (PCE) ( $)$ of $1.06 \%$ under simulated AM 1.5 illuminations was achieved successfully.

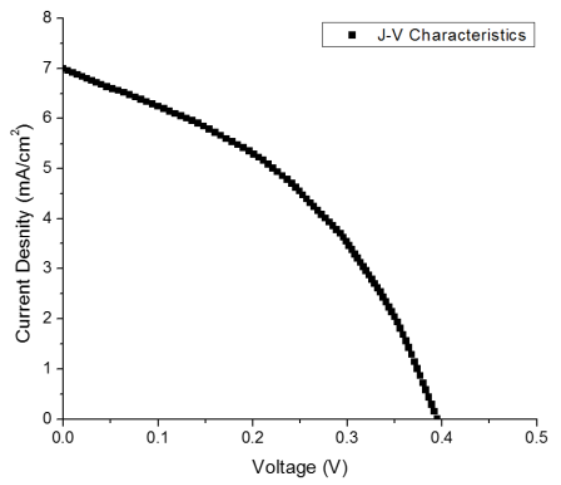

Fig. $6 \mathrm{~J}-\mathrm{V}$ characteristics of solar cell

\section{Conclusion}

In the present study, tin monosulfide $(\mathrm{SnS})$ films are prepared successfully using spray pyrolysis technique. The effect of process parameters such as substrate temperature, carrier gas pressure and spraying rate on the optical, structural and morphological properties of film is studied in detailed. The substrate temperature has demonstrated prominent effect on the optical, structural and morphological properties. The substrate temperature is varied from $280^{\circ} \mathrm{C}$ to $440^{\circ} \mathrm{C}$. The optimum results are achieved at $360^{\circ} \mathrm{C}$ temperature. However, the carrier gas pressure and spraying rate does not significantly affect the optical and structural properties of the films. At the end of all experiments, the optimum conditions achieved are: $360^{\circ} \mathrm{C}$ substrate temperature, 2 bar carrier gas pressure and $5 \mathrm{ml} / \mathrm{min}$ flow rate. In addition, the solar cell is fabricated with the film prepared using this optimum deposition condition. The solar cell is fabricated as FTO/SnS/CdS/ZnO/Al:ZnO/FTO. $1.06 \%$ of 
promising solar cell efficiency is achieved successfully. This optimized SnS thin films can be further applied in tandem cells.

\section{Acknowledgements}

The authors would like to acknowledge the sophisticated instrumentation center and Department of Chemical Engineering of S.V. National Institute of Technology, Surat.

\section{References}

[1] J. V. Gohel, A. K. Jana, and M. Singh, "Highly enhanced photocurrent of novel quantum-dot-co-sensitized $\mathrm{PbS}-\mathrm{Hg}$ / $\mathrm{CdS} / \mathrm{Cu}: \mathrm{ZnO}$ thin films for photoelectrochemical applications,” Appl. Phys. A, vol. 123, no. 8, pp. 1-12, 2017.

[2] M. Lanjewar and J. V. Gohel, "Enhanced performance of Ag-doped $\mathrm{ZnO}$ and pure $\mathrm{ZnO}$ thin films DSSCs prepared by sol-gel spin coating,” Inorg. Nano-Metal Chem., vol. 47, no. 7, pp. 1090-1096, 2017.

[3] S. B. Patel and J. V. Gohel, "Recent developments in $\mathrm{Cu}_{2} \mathrm{ZnSnS}_{4}$ (CZTS) preparation, optimization and its application in solar cell development and photocatalytic applications“, Mater. Res. Forum, 2017.

[4] V. R. Minnam Reddy, S. Gedi, C. Park, M. R.w, and R. R. Ramakrishna, "Development of sulphurized SnS thin film solar cells,” Curr. Appl. Phys., vol. 15, no. 5, pp. 588-598, 2015.

[5] Y. Akaltun, A. Astam, A. Cerhan, and Tuba Cayir, "Effect of thickness on electrical properties of SILAR deposited SnS thin films," AIP Conf. Proc., vol. 1722, 2016.

[6] R. Mariappan, T. Mahalingam, and V. Ponnuswamy, "Preparation and characterization of electrodeposited SnS thin films," Optik (Stuttg)., vol. 122, no. 24, pp. 2216-2219, 2011.

[7] A. Tanuševski and D. Poelman, "Optical and photoconductive properties of SnS thin films prepared by electron beam evaporation," Sol. Energy Mater. Sol. Cells, vol. 80, no. 3, pp. 297-303, 2003.

[8] T. Sall, M. Mollar, and B. Marí, "Substrate influences on the properties of SnS thin films deposited by chemical spray pyrolysis technique for photovoltaic applications," J. Mater. Sci., vol. 51, no. 16, pp. 7607-7613, 2016.

[9] N. Kumari, J. V. Gohel, and S. R. Patel, "Multi-response optimization of ZnO thin films using Grey-Taguchi technique and development of a model using ANN," Opt. - Int. J. Light Electron Opt., vol. 144, pp. 422-435, 2017.

[10] F. Alam and V. Dutta, "Tin sulfide ( $\mathrm{SnS}$ ) nanostructured films deposited by continuous spray pyrolysis (CoSP) technique for dye-sensitized solar cells applications,” Appl. Surf. Sci., vol. 358, pp. 491-497, 2015.

[11] U. Chalapathi, B. Poornaprakash, and S. H. Park, "Chemically deposited cubic SnS thin films for solar cell applications," Sol. Energy, vol. 139, pp. 238-248, 2016.

[12] S. Gedi, V. R. Minna Reddy, B. Pejjai, C. W. Jeon, C. Park, and R. R. Kt, "A facile inexpensive route for SnS thin film solar cells with $\mathrm{SnS}_{2}$ buffer,” Appl. Surf. Sci., vol. 372, pp. 116-124, 2016.

[13] T. Sall, B. M. Soucase, M. Mollar, and J. A. Sans, "SnS Thin Films Prepared by Chemical Spray Pyrolysis at Different Substrate Temperatures for Photovoltaic Applications,” J. Electron. Mater., vol. 46, no. 3, pp. 1714-1719, 2017.

[14] M. Patel, I. Mukhopadhyay, and A. Ray, "Molar optimization of spray pyrolyzed SnS thin films for photoelectrochemical applications,” J. Alloys Compd., vol. 619, pp. 458-463, 2015. 